\title{
Comparison of Spot Urine Protein/Creatinine Ratio, Spot Urine Protein/ Osmolality Ratio with Measured 24-Hour Urine Protein in HIV Subjects in Nigeria
}

\section{Ernest Ndukaife Anyabolu ${ }^{1,2}$, Innocent ljezie Chukwuonye ${ }^{2 *}$, Monica Mabayoje ${ }^{3}$, ArodiweEjike ${ }^{4}$, Chinwuba K ljoma ${ }^{4}$, Solomon Kadiri ${ }^{5}$ and} EfosaOviasu $^{6}$

${ }^{1}$ Division of Nephrology, Department of Internal Medicine, Imo State University Teaching Hospital, Orlu, Nigeria.

${ }^{2}$ Division of Nephrology, Department of Internal Medicine, Federal Medical Centre Owerri, Nigeria

${ }^{3}$ Division of Nephrology, Department of Internal Medicine, Lagos University Teaching Hospital, Lagos, Nigeria

${ }^{4}$ Division of Nephrology, Department of Internal Medicine, University of Nigeria Teaching Hospital, Enugu, Nigeria

${ }^{5}$ University College Hospital, Ibadan, Nigeria

${ }^{6}$ Division of Nephrology, Department of Internal Medicine, University of Benin Teaching Hospital, Benin City, Nigeria

\begin{abstract}
Background and Objectives: Urine protein examination is a veritable tool in the management of renal diseases. Proteinuria evaluation from 24-hour urine collection is the gold standard. Prompt urine protein assessment from spot urine sample has become necessary to eliminate inaccuracies inherent in timed urine collection. This study aims at comparing spot urine protein/creatinine ratio (SUPCR) and measured 24-hour urine protein (24 HUP), and also spot urine protein/osmolality ratio (SUPOR) and 24 HUP against measured 24-hour urine protein (24 HUP) for assessment of proteinuria in human immunodeficiency virus (HIV) subjects.
\end{abstract}

Methodology: Three hundred and ninety three HIV subjects from the HIVIAIDS clinic and 136 age- and sexmatched non-HIV subjects as Control. Investigations performed included 24-hour urine protein (24 HUP), spot urine protein (SUP), spot urine creatinine (SUCr), spot urine osmolality (SUOsm), fasting blood sugar (FBS), urinalysis, HIV screening and confirmatory test, electrolyte, urea and creatinine. SUPCR and SUPOR were calculated. Correlation statistics, $2 \times 2$ contingency table analysis, receiver operator characteristics (ROC) Curve analysis and Bland Altman plots were used to compare SUPCR and 24 HUP, and also SUPOR and 24 HUP in HIV subjects and control. SPSS version 17 and Medcal statistical software were used to analyze the data. $P<0.050$ was taken as statistically significant.

Results: Using the $2 \times 2$ contingency table in the HIV subjects, the Sensitivity for SUPCR and SUPOR with 24 HUP was $43.4 \%$ and $11.5 \%$ respectively. Specificity for SUPCR and SUPOR with 24 HUP was $92.9 \%$ and $99.2 \%$ respectively. The SUPCR had a correlation $(r)$ of $0.734(p<0.001)$ with 24 HUP. In addition, SUPOR had a correlation coefficient of 0.417 ( $p<0.001$ ) with 24 HUP. Using the Bland Altman plots, SUPCR compared with 24HUP the limits of agreement were $+0.361 \mathrm{~g} /$ day to $-0.248 \mathrm{~g} /$ day in HIV subjects. In addition for SUPOR the limits of agreements were $+0.440 \mathrm{~g} /$ day to- $0.180 \mathrm{~g} / \mathrm{day}$ in HIV subjects. The bias was $0.060 \mathrm{~g} /$ day and $0.130 \mathrm{~g} /$ day for SUPCR and SUPOR respectively. The receiver operating characteristics (ROC) curve showed that SUPCR randomly chosen value of 0.042 $\mathrm{mg} / \mathrm{mg}$ and SUPOR chosen value of $0.010 \mathrm{mg} / \mathrm{dl} / \mathrm{mOsm} / \mathrm{kg} \mathrm{H}_{2} \mathrm{O}$ predicted $24 \mathrm{HUP}$ at urinary excretion threshold of $0.150 \mathrm{~g}$.

Conclusion: The SUPCR and SUPOR are reliable tests, for quantifying proteinuria in HIV subjects, and should be used in assessment of proteinuria in HIV subjects in Sub Saharan African countries.

Keywords: Proteinuria; HIV; 24 HUP; SUPCR; SUPOR; Bland Altman plot; ROC curve

\section{Introduction}

Chronic kidney disease (CKD) is defined by the presence of kidney damage or glomerular filtration rate (GFR) less than $60 \mathrm{ml} / \mathrm{min} / 1.73$ $\mathrm{m}^{2}\left(1.0 \mathrm{ml} / \mathrm{s} / 1.73 \mathrm{~m}^{2}\right)$ for three or more months, irrespective of cause [1]. HIV infection is commonly associated with chronic kidney disease [2]. Accurate and fast diagnostic tools are necessary to diagnose and monitor HIV patients who may have CKD. In majority of subjects with CKD, the presence of CKD can be detected with 2 tests. These tests include a urine test for the detection of proteinuria and a blood test to estimate the GFR. These two tests are commonly used by Nephrologists for detection of CKD in Sub Saharan Africa and other parts of the world.

Proteinuria is the commonest marker of CKD in adults and contributes to its progression by several mechanisms; and appropriate interventions that reduce proteinuria also improve patient outcome [3]. Urine protein estimation is one of the key parameters in the diagnosis and monitoring of renal functions in HIV-related renal disease states [4]. Evaluation of protein from 24-hour urine collection collection is the traditional and gold standard diagnostic test for quantification of proteinuria in the general population including in HIV subjects. The 24 HUP sample collection is often difficult, tedious, time-consuming, and is also riddled with errors [5,6]. Due to the problems associated with 24

*Corresponding author: Chukwuonye II, Consultant Nephrologist/Physician Federal Medical Centre Umuahia, Nigeria, Tel: +2348038774307; Email: chukwuonye4@yahoo.com

Received February 21, 2015; Accepted March 23, 2015; Published March 31 2015

Citation: Anyabolu EN, Chukwuonye II, Mabayoje M, Ejike A, ljoma CK, et al. (2015) Comparison of Spot Urine Protein/Creatinine Ratio, Spot Urine Protein/Osmolality Ratio with Measured 24-Hour Urine Protein in HIV Subjects in Nigeria. J AIDS Clin Res 6: 445. doi:10.4172/2155-6113.1000445

Copyright: (c) 2015 Anyabolu EN, et al. This is an open-access article distributed under the terms of the Creative Commons Attribution License, which permits unrestricted use, distribution, and reproduction in any medium, provided the original author and source are credited. 
Citation: Anyabolu EN, Chukwuonye II, Mabayoje M, Ejike A, ljoma CK, et al. (2015) Comparison of Spot Urine Protein/Creatinine Ratio, Spot Urine Protein/Osmolality Ratio with Measured 24-Hour Urine Protein in HIV Subjects in Nigeria. J AIDS Clin Res 6: 445. doi:10.4172/21556113.1000445

Page 2 of 5

HUP collection, some alternatives for the quantification of proteinuria in HIV seropositive subjects have been considered. The alternatives include urinary dipsticks protein estimation, SUPCR, and SUPOR.

Dipstick urinalysis protein estimation is known to have a poor sensitivity and specificity profile for establishing significant proteinuria or quantitative change in proteinuria [7]. Measurement of albumin or total protein concentration in a spot sample by tests like SUPCR and SUPOR avoids the need for collection of a timed urine specimen but is affected by some factors including the state of hydration, sex, and age [4]. However, some studies have demonstrated that SUPCR in a random, single voided urine sample reflects 24 -hour urine protein [810]. Random and morning urinary protein/osmolality ratio has also been found to reflect 24 HUP excretion [11].

There is paucity of data on HIV subjects comparing SUPGR against 24 HUP and SUPOR against 24 HUP, emanating from Sub Saharan Africa. In addition, with the increasing incidence of HIV infection in the region, it is pertinent that faster, cheaper, simpler, and evidencebased reliable methods of quantifying proteinuria in HIV patients be adopted. This will help in no small measure to improve the management of this group of patients in Sub Saharan African countries. Bearing this in mind we decided to carry out this study to validate the use of SUPCR, and SUPOR in quantifying proteinuria in HIV subjects, by comparing each of them respectively, with 24 HUP.

\section{Materials and Methods}

This was a cross-sectional comparative study of SUPCR and SUPOR against the "gold Standard," 24 HUP, in newly-diagnosed HIVseropositive subjects. The study was carried out between March, 2011 and August, 2011 in Federal Medical Centre, Owerri (FMC), Imo State, Nigeria. The subjects consisted of 393 newly-diagnosed, drug- naive, HIV-seropositive adult subjects within the age range of 18-65 years, and 136 age- and sex-matched HIV-sero-negative subjects as control. Exclusion criteria included subject below 18 years or above 65 years, febrile illnesses, evidence of heart failure, urinary tract infection, diabetes mellitus, hypertension, evidence of urological disease, and use of drugs that could interfere with urinary creatinine excretion. The same exclusion criteria applied to the control group. An interviewer structured questionnaire was administered and relevant data collected. These included patient's age, sex, diagnosis and co-morbidities (diabetic mellitus, hypertension etc.).

Approval for this study was obtained from the Ethical and Research Committee of FMC Owerri. Investigations performed by the subjects included: HIV screening and confirmatory tests, SUP, SUCr, SUOsm, serum creatinine, 24 HUP, FBS, and urinalysis.

Clear instructions were given to all the subjects on how to collect 24-hour urine sample. 24-hour urine protein was measured in the urine samples thus collected. A day-time random spot urine sample was collected at the end of 24-hour urine sample collection and was used in calculating SUPCR and SUPOR. This was to facilitate rapid analysis in our laboratory [12]. Urine protein was measured by photometric method, urine osmolality by freezing point depression method (using Precision System Osmette 5002 osmometer) and creatinine by modified Jaffe method. All the laboratory tests were carried out in the laboratory of FMC, Owerri, while urine osmolality tests were done by E,N Anyabolu. FMC, Owerri, is one of two tertiary health institutions in the State, and has a good number of laboratory scientists. SUPCR and SUPOR were determined.

\section{Statistical analysis}

SPSS version 17.0 (SPSS Inc., Chicago, Il, USA) statistical software was used to analyze the data. The $2 \times 2$ contingency tables were used to calculate the sensitivity, specificity, positive predictive value, negative predictive value and accuracy obtained. The cut-off value for the 2 by 2 table was 24 HUP $0.150 \mathrm{~g}$, SUPCR $0.150 \mathrm{mg} / \mathrm{mg}$, SUPOR $0.150 \mathrm{mg} / \mathrm{dL} /$ $\mathrm{mOsm} / \mathrm{Kg} \mathrm{H}_{2} \mathrm{O}$. Predictive indices of SUPCR and SUPOR for $24 \mathrm{HUP}$ were determined. The strength of association between the SUPCR and against 24 HUP, and also SUPOR and against 24 HUP was determined by correlation statistics. $\mathrm{P}<0.05$ was taken as statistically significant. Bland Altman's plot was used to compare SUPCR, SUPOR, each with 24 HUP (Medcalc statistical software) BLAND ALTMAN [13] Cutoff values, sensitivity and specificity of SUPCR and SUPOR were assessed for predicting $24 \mathrm{HUP}$ excretion "threshold" of $0.150 \mathrm{~g} /$ day by ROC curve. These four instruments, namely $2 \times 2$ contingency table analysis, correlation statistics, receiver operator characteristics (ROC) curve analysis and Bland Altman plots were used to compare SUPCR, SUPOR with 24 HUP in HIV subjects and Control. $\mathrm{P}<0.05$ was taken as statistically significant

\section{Results}

The mean age of the HIV subjects was $39 \pm 11$ years, and their age ranged between 18 and 65 years. Out of 393 HIV subjects, $283(72.0 \%)$ were females, while $110(28.0 \%)$ were males. The control consisted 136 subjects, of these $98(72.1 \%)$ were females, while 38 (27.9\%) were males.

The female/male ratio was approximately $3: 1$ in both the HIV subjects and control subjects. However, 22 subjects were excluded from the study on account of inadequate 24-hour urine collection.

In the HIV subjects, the mean 24HUP, SUPCR, and SUPOR were $0.187 \pm 0.290 \mathrm{~g}, 0.133 \pm 0.371 \mathrm{mg} / \mathrm{mg}$, and $0.035 \pm 0.050 \mathrm{mgdl} / \mathrm{mOsm} /$ $\mathrm{kg} \mathrm{H}_{2} \mathrm{O}$ respectively. In the Control, the mean $24 \mathrm{HUP}$, SUPCR, and SUPOR were; $0.095 \pm 0.087 \mathrm{~g}, 0.082 \pm 0.163 \mathrm{mg} / \mathrm{mg}, 0.042 \pm 0.135$ $\mathrm{mg} / \mathrm{dl} / \mathrm{mOsm} / \mathrm{kg} \mathrm{H}_{2} \mathrm{O}$ respectively. There was statistically significant difference using 24 HUP in the HIV subjects and the Controls, $\mathrm{p}<0.001$. In contrast, SUPCR and SUPOR showed no statistically significant difference between the HIV subjects and the Control, $\mathrm{p}=0.120$ and $\mathrm{p}=0.357$ respectively $($ Table 1$)$.

Using the $2 \times 2$ contingency table, in HIV subjects, the sensitivity, specificity, positive predictive value (PPV), negative predictive values (NPV), and accuracy for SUPCR were 43\%, 92.9\%, 74.6\%, 92.8\% and $76.8 \%$ respectively. In SUPOR, the sensitivity, specificity, PPV, NPV, and accuracy were $11 \%, 99.2 \%, 87.5 \%, 69.9 \%$, and $70.6 \%$ respectively In addition, in the control the sensitivity, specificity, PPV, NPV, and

\begin{tabular}{|l|c|c|c|}
\hline Variable (mean) & $\begin{array}{c}\text { All subjects } \\
(\mathbf{n = 5 2 9 )}\end{array}$ & $\begin{array}{c}\text { HIV subjects } \\
(\mathbf{n = 3 9 3 )}\end{array}$ & $\begin{array}{c}\text { P value } \\
(\mathbf{n = 1 3 6 )}\end{array}$ \\
\hline 24HUP $(\mathrm{g} \pm \mathrm{SD})$ & $0.162 \pm 0.256$ & $0.187 \pm 0.290$ & $<0.095 \pm 0.087$ \\
\hline SUPCR $(\mathrm{mg} / \mathrm{mg} \pm \mathrm{SD})$ & $0.120 \pm 0.330$ & $0.133 \pm 0.371$ & $0.082 \pm 0.163$ \\
\hline SUPOR $\left(\mathrm{mg} / \mathrm{dl} / \mathrm{mOsmol} / \mathrm{Kg} \mathrm{H} \mathrm{H}_{2} \mathrm{O} \pm \mathrm{SD}\right)$ & $0.037 \pm 0.081$ & $0.035 \pm 0.050$ & 0.120 \\
\hline
\end{tabular}

24HUP: 24-Hour Urine Protein; SUPCR: Spot Urine Protein/Creatinine Ratio; SUPOR: Spot Urine Protein/Osmolality Ratio; SD: Standard Deviation

Table 1: Daily urine protein estimation of the study population. 
Citation: Anyabolu EN, Chukwuonye II, Mabayoje M, Ejike A, ljoma CK, et al. (2015) Comparison of Spot Urine Protein/Creatinine Ratio, Spot Urine Protein/Osmolality Ratio with Measured 24-Hour Urine Protein in HIV Subjects in Nigeria. J AIDS Clin Res 6: 445. doi:10.4172/21556113.1000445

Page 3 of 5

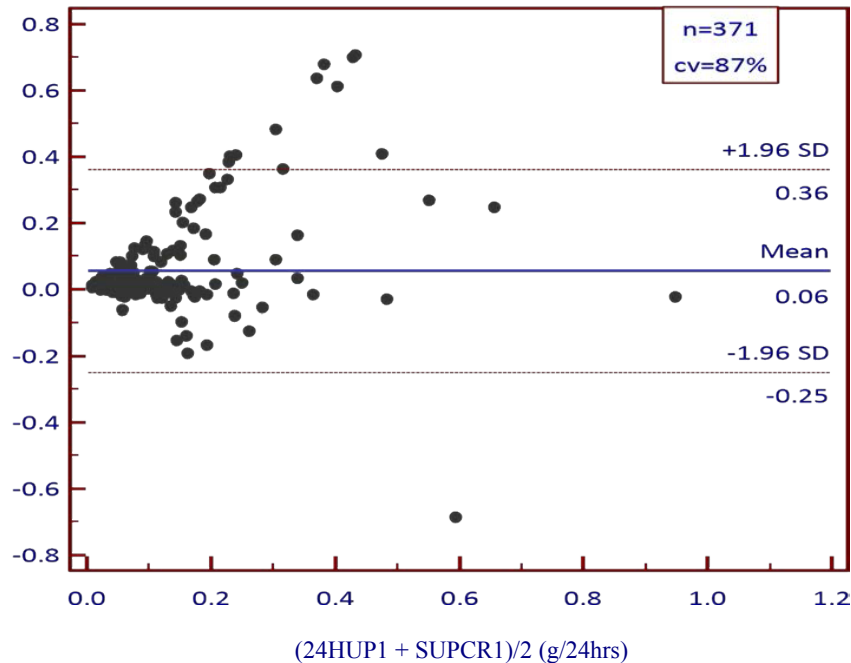

$\%$ outliers $=2.5 \%$

24HUP: 24-Hour Urine Protein; SUPCR: Spot Urine Protein/Creatinine Ratio; SUPOR: Spot Urine Protein/Osmolality Ratio; SD: Standard Deviation; n=number of HIV subjects, cv: Coefficient of Variation; hrs: Hours.

Figure 1A: Bland Altman plots between 24HUP and SUPCR plus the observed mean difference and $95 \%$ limits of agreement in HIV subject.

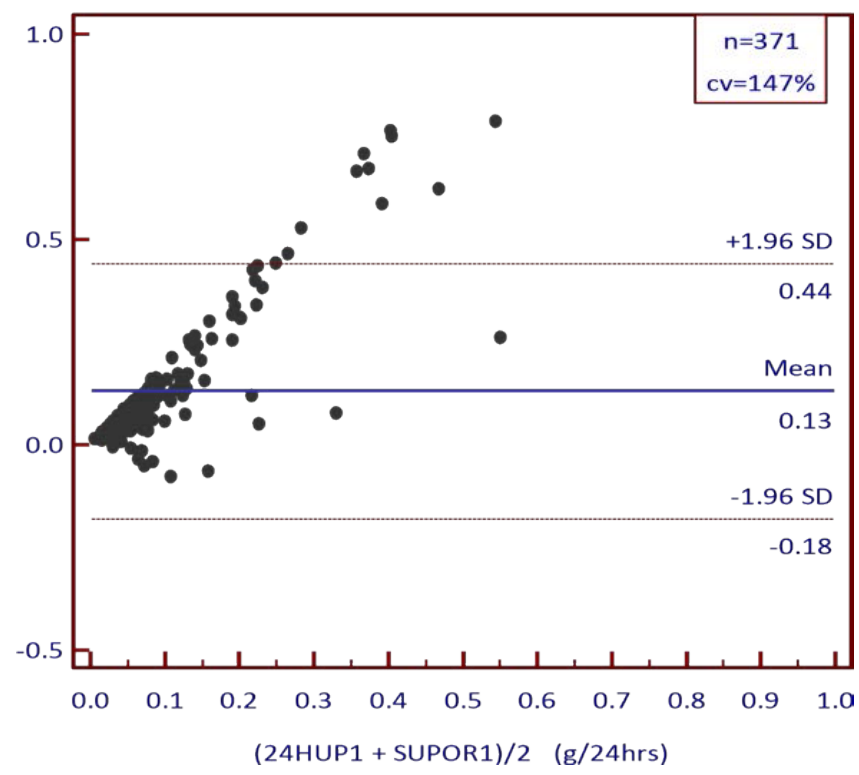

$\%$ outliers $=3.0 \%$

24HUP: 24-Hour Urine Protein; SUPOR: Spot Urine Protein/Osmolality Ratio; SD: Standard Deviation; $n=$ number of HIV subjects, cv: Coefficient of Variation hrs: Hours.

Figure 1B: Bland Altman plots between 24 HUP and SUPOR plus the observed mean difference and $95 \%$ limits of agreement in HIV subjects. accuracy for SUPCR were $20.0 \%, 95.6 \%, 44.4 \%, 87.4 \%$, and $84.5 \%$ respectively. The values for SUPOR for sensitivity, specificity, PPV, NPV, and accuracy were; $15.0 \% 98.2 \%, 60.0 \%, 87.0 \%$, and $86.0 \%$ respectively.

Table 2 shows the correlation of 24 HUP with SUPCR and SUPOR respectively, in HIV subjects. SUPCR was found to had a correlation coefficient of $0.734(\mathrm{p}<0.001)$. SUPOR was found to have a correlation coefficient of $0.417(p=0.001)$ in HIV subjects. In addition, in the Control, SUPCR was found to have a correlation of $0.518(\mathrm{p}<0.001)$ SUPOR also had a correlation $0.336(\mathrm{p}<0.001)$.

Figures 1A-1D showed the Bland Altman plots for SUPCR, and SUPOR when compared individually with 24 HUP in HIV and control subjects. Tables 3,4 summarize the findings.

Figures 1F,1G showed ROC of SUPCR and SUPOR test result variables against $24 \mathrm{HUP}$ as standard in study population. The positive actual state or cutoff was $\geq 0.150 \mathrm{~g}$. In HIV subjects, SUPCR had an AUROC (area under receiver operator curve) of $0.678, \mathrm{p}<0.001$, confidence interval 95\% (0.617 to 0.738 ), while SUP\OR had an AUROC of $0.678, \mathrm{p}<0.001$, confidence interval $95 \%$ (0.619 to 0.736 ). In the controls, SUPCR had an AUROC of 0.753, $\mathrm{p}<0.001$, confidence interval 95\% (0.633 to 0.872), while SUPOR had an AUROC of 0.614 , $\mathrm{p}<0.001$, confidence interval $95 \%$ (0.485 to 0.744$)$ The ROC analysis showed that SUPCR of $0.042 \mathrm{mg} / \mathrm{mg}$ (sensitivity $91 \%$ and specificity $90 \%$ ) and SUPOR value of $0.010 \mathrm{mg} / \mathrm{dl} / \mathrm{mOsm} / \mathrm{kg} \mathrm{H}_{2} \mathrm{O}$ (sensitivity $91 \%$, and specificity $90 \%$ ) predicted $24 \mathrm{HUP}$ at $0.150 \mathrm{~g}$.

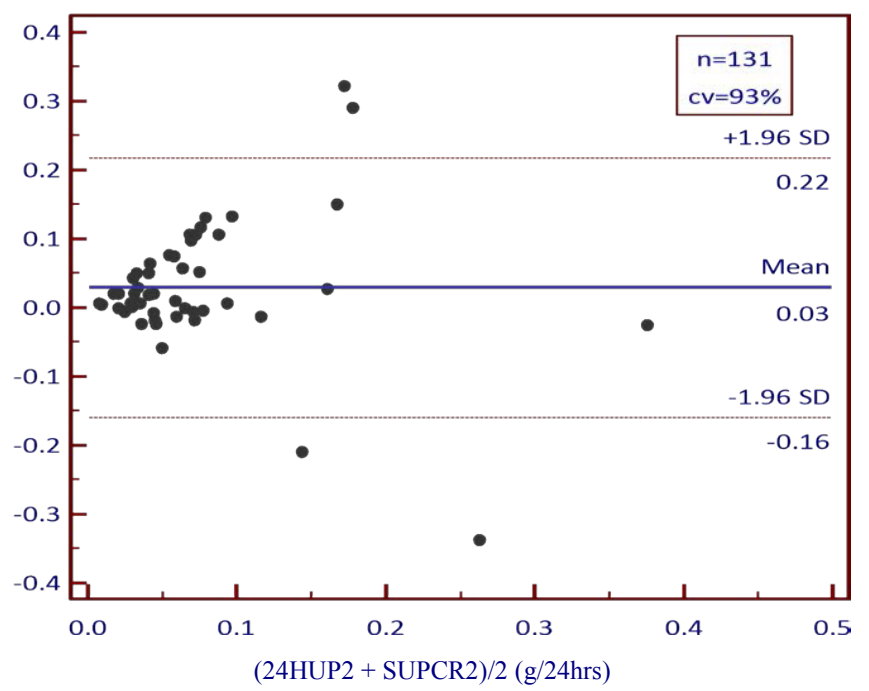

$\%$ outliers $=3.0 \%$

24HUP: 24-Hour Urine Protein; SUPCR: Spot Urine Protein/Creatinine Ratio; SD: Standard Deviation; $n=$ number of HIV subjects, cv: Coefficient of Variation hrs: Hours.

Figure 1C: Bland Altman plots between 24 HUP and SUPCR plus the observed mean difference and $95 \%$ limits of agreement in controls.

\begin{tabular}{|c|c|c|c|c|c|}
\hline Study Group & $\begin{array}{c}\text { 24HUP } \\
\text { (g/24hours) } \\
\text { (mean } \pm \text { SD) }\end{array}$ & $\begin{array}{c}\text { SUPCR } \\
\text { (mean } \pm \text { SD) }\end{array}$ & r & $\begin{array}{c}\text { P } \\
\text { Value }\end{array}$ & $\begin{array}{c}\text { SUPOR } \\
\text { (mean } \pm \text { SD) }\end{array}$ \\
\hline $\begin{array}{c}\text { HIV } \\
\text { subject } \mathrm{n}=375\end{array}$ & $0.187 \pm 0.290$ & $0.133 \pm 0.371$ & 0.734 & $<0.001$ & $0.035 \pm 0.050$ \\
\hline
\end{tabular}

24HUP: 24-Hour Urine Protein; SUPCR: Spot Urine Protein/Creatinine Ratio; SUPOR: Spot Urine Protein/Osmolality Ratio; r: correlation coefficient. Table 2: Correlation of 24HUP with SUPCR and SUPOR for assessment of 24-hour urine protein excretion in HIV subjects. 
Citation: Anyabolu EN, Chukwuonye II, Mabayoje M, Ejike A, ljoma CK, et al. (2015) Comparison of Spot Urine Protein/Creatinine Ratio, Spot Urine Protein/Osmolality Ratio with Measured 24-Hour Urine Protein in HIV Subjects in Nigeria. J AIDS Clin Res 6: 445. doi:10.4172/21556113.1000445

Page 4 of 5

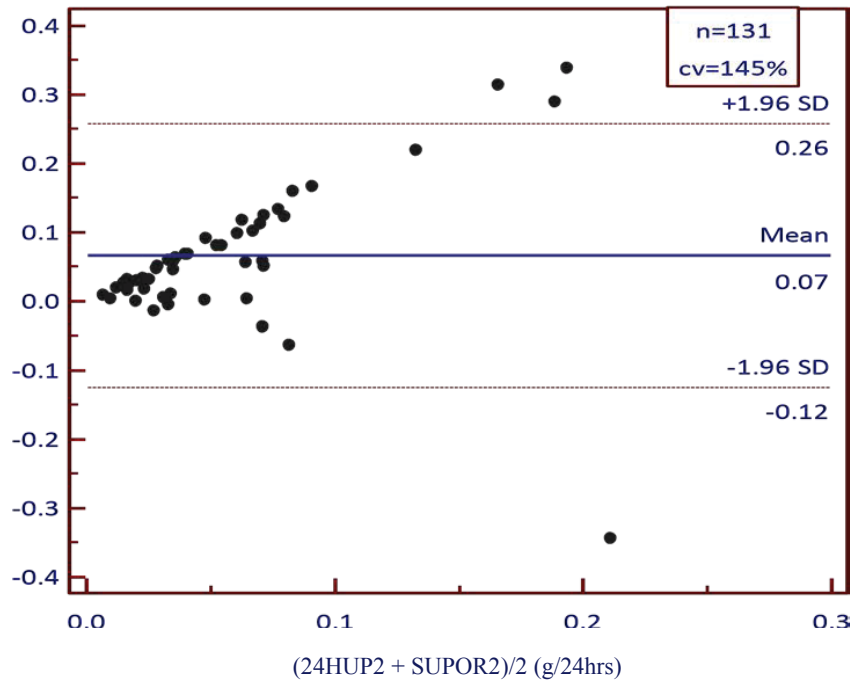

Figure 1D: Bland Altman plots between 24 HUP and SUPOR plus the observed mean difference and $95 \%$ limits of agreement in controls.

$\%$ outliers $=3.1 \%$

24HUP: 24-Hour Urine Protein; SUPOR: Spot Urine Protein/Osmolality Ratio SD: Standard Deviation; $n=$ number of HIV subjects, cv: Coefficient of Variation hrs: Hours.

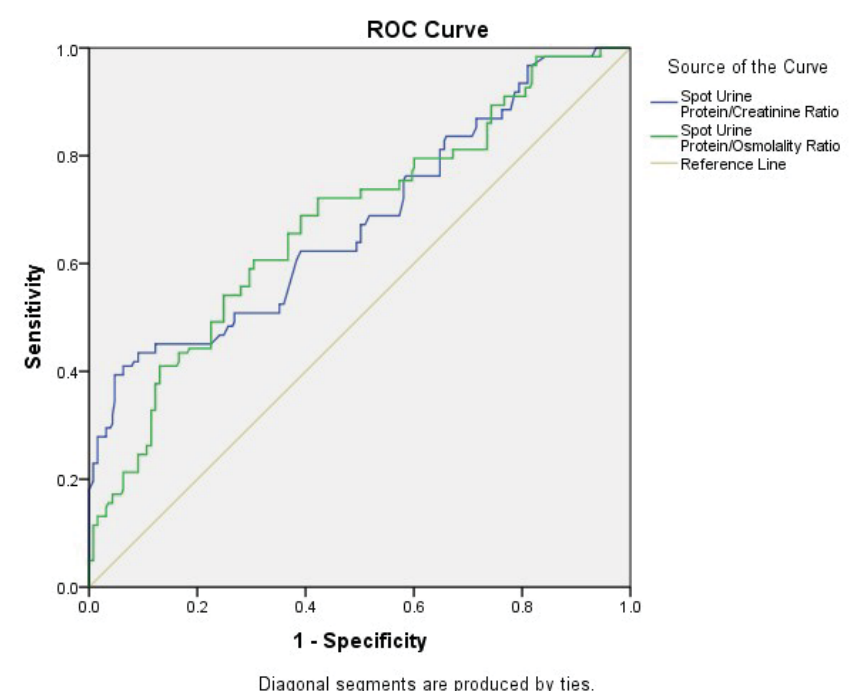

Cutoff $=0.150 \mathrm{~g}$

ROC: Receiver Operator Curve; 24HUP: 24-Hour Urine Protein; SUPCR: Spot Urine Protein/Creatinine Ratio; SUPOR: Spot Urine Protein/Osmolality Ratio.

Figure 1E: ROC curve of SUPCR and SUPOR test result variables against 24HUP as standard in HIV subjects.

\begin{tabular}{|c|c|c|}
\hline g/24hrs & SUPCR $v$ 24HUP & SUPOR v 24HUP \\
\hline Bias & 0.060 & 0.130 \\
\hline Precision (+) & 0.214 & 0.289 \\
\hline Precision (-) & -0.098 & 0.164 \\
\hline Limits of Agreement (+) & 0.361 & 0.440 \\
\hline Limits of Agreement (-) & 0.248 & 0.180 \\
\hline
\end{tabular}

24HUP: 24-Hour Urine Protein; SUPCR: Spot Urine Protein/Creatinine Ratio; SUPOR: Spot Urine Protein/Osmolality Ratio; SD: Standard Deviation.

Table 3: Summary of Bland Altman Plots in HIV subjects.

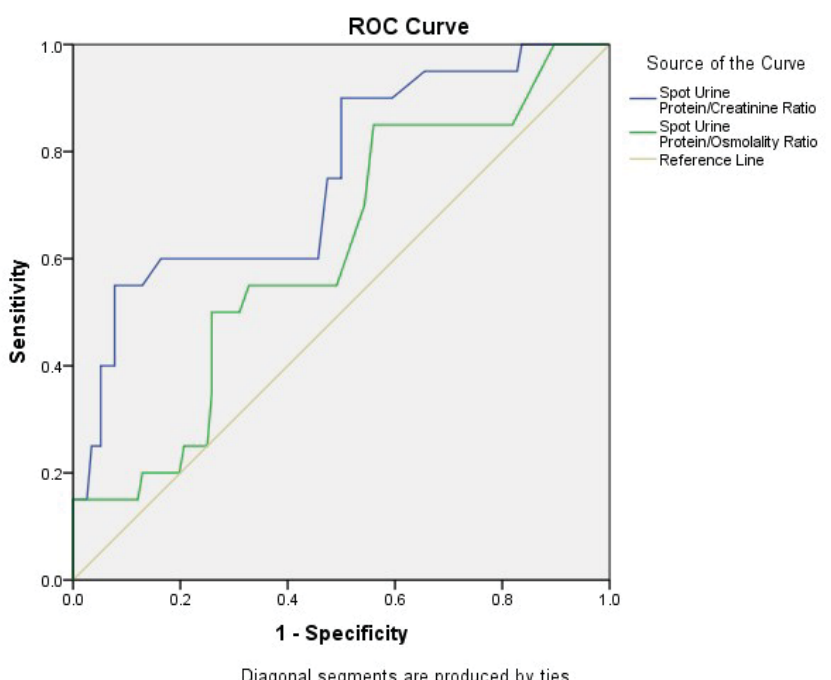

Cutoff $=0.150 \mathrm{~g}$

ROC: Receiver Operator Curve; 24HUP: 24-Hour Urine Protein; SUPCR: Spot Urine Protein/Creatinine Ratio; SUPOR: Spot Urine Protein/Osmolality Ratio.

Figure 1F: ROC curve of SUPCR and SUPOR test result variables against 24HUP as standard in controls.

\begin{tabular}{|c|c|c|}
\hline g/day & SUPCR v 24HUP & SUPOR v 24HUP \\
\hline Bias & 0.030 & 0.070 \\
\hline Precision (+) & 0.125 & 0.164 \\
\hline Precision (-) & 0.067 & 0.30 \\
\hline Limits of Agreement (+) & 0.217 & 0.258 \\
\hline Limits of Agreement (-) & 0.159 & 0.124 \\
\hline
\end{tabular}

Table 4: Summary of Bland Altman plots in the control subjects.

\section{Discussion}

This study compared the SUPCR and SUPOR against "gold standard" 24 HUP in HIV subjects. In the 2 by 2 table analysis in HIV subjects at cut off of 0.150 for the three methods, the sensitivity for SUPCR, and SUPOR was, $43 \%$, and $11 \%$ respectively, while the specificity was $92 \%$, and $99.2 \%$ respectively in predicting 24 HUP. These shows that both spot urine tests had low sensitivity and high specificity. This tends to suggest that they are both poor screening tests, good diagnostic tests. Similar results were also obtained in the control. We did not, however, evaluate these predictive indices of SUPCR and SUPOR for 24 HUP at higher cut-off values of proteinuria.

The correlation of SUPCR and SUPOR, with 24 HUP, respectively, in the HIV subjects, showed This study showed that SUPCR had a high correlation coefficient (0.734) with $24 \mathrm{HUP}(\mathrm{r}=0.734, \mathrm{p}<0.001)$, while SUPOR had a moderate correlation (0.417) with 24 HUP ( $r=0.417$, $\mathrm{p}<0.001)$ in HIV subjects. The $\mathrm{p}$ values were significant in both cases. In the Control the SUPCR had a moderate correlation (0.518), while SUPOR had a mild (0.336) correlation. This correlation values, of SUPCR with 24 HUP, in HIV subjects, where slightly lower than those reported in some studies [14-18]. None the less one of these studies was conducted in an HIV population, while the other was in a general population. This study also showed lower correlation values for SUPCR and 24 HUP, compared with those of two previous studies $[11,12]$.

Bland-Altman analysis is typically used to compare measurement techniques against a reference value, usually an accepted gold standard. 
Citation: Anyabolu EN, Chukwuonye II, Mabayoje M, Ejike A, ljoma CK, et al. (2015) Comparison of Spot Urine Protein/Creatinine Ratio, Spot Urine Protein/Osmolality Ratio with Measured 24-Hour Urine Protein in HIV Subjects in Nigeria. J AIDS Clin Res 6: 445. doi:10.4172/21556113.1000445

Page 5 of 5

We want to know by how much the new method is likely to differ from the old; if this is not enough to cause problems in clinical interpretation we can replace the old method by the new or use the two interchangeably." [13]. Bland Altman plot was used in this study to compare SUPCR and SUPOR against 24HUP, respectively. The bias and precisions were low, and though good correlation was observed between SUPCR, SUPOR with $24 \mathrm{HUP}$ in this study, it is expedient that reasonable limits of agreement be demonstrated for them to be used interchangeably. The $95 \%$ limits of agreements values were within acceptable range.

We found, in this study, for both SUPCR and SUPOR, when each was compared with 24 HUP, that the results were similar within $95 \%$ limits of agreement. These findings, and correlation, strongly suggest that both tests may be used interchangeably with the 24 HUP, especially the SUPCR that had a high correlation with 24 HUP in HIV subjects. Similar results were reported by previous studies which also showed that SUPCR and 24 HUP could be used interchangeably in HIV subjects and in the general population $[14,18]$. This is in keeping with findings from some previous studies $[14,18]$.

The predictive indices of SUPCR and SUPOR against measured 24 HUP in HIV were also evaluated using the ROC curves. Based on ROC comparison, our study showed low sensitivity and specificity for SUPCR (at values $\geq 0.150 \mathrm{mg} / \mathrm{mg}$ ) and SUPOR (at values $\geq 0.150 \mathrm{mg} / \mathrm{dl} / \mathrm{mOsm} /$ $\mathrm{Kg} \mathrm{H}_{2} \mathrm{O}$ ) methods in predicting $24 \mathrm{HUP}$ of $\geq 0.150 \mathrm{~g}$ in HIV subjects. There was no difference between SUPCR and SUPOR in predicting 24 HUP at this level. This is similar to the findings reported by two studies with slightly higher AUROC $[19,20]$. This is in keeping with some earlier studies $[19,20]$. However SUPCR was found to be better than SUPOR when compared with 24 HUP in another study [21]. In addition, with further evaluation in our study, we found that in SUPCR, of $0.042 \mathrm{mg} /$ $\mathrm{mg}$ represented the best threshold to reliably predict $24 \mathrm{HUP}$ of $0.150 \mathrm{~g}$, with high sensitivity, and high specificity in this study. This is consistent with previously published reports [20-22]. In addition, SUPOR of 0.01 $\mathrm{mg} / \mathrm{dl} / \mathrm{mOsm} / \mathrm{kg} \mathrm{H}_{2} \mathrm{O}$ represented the best threshold to reliably predict 24 HUP of $0.150 \mathrm{~g}$, with high sensitivity and high specificity. This is similar to the study by Wilson et al. [11] in which they found SUPOR of 0.120 with sensitivity of $95 \%$ and specificity of $93 \%$ to represent normal range proteinuria in 24-hour urine collection. This compared to a SUPCR of less than 0.05 (sensitivity $96 \%$, specificity $90 \%$ ).

\section{Conclusion}

SUPCR is a fast, convenient and reliable method of estimating proteinuria in both HIV and non HIV population from the correlation, Bland Altman plot analysis and ROC curves. The same applies to the SUPOR test. HIV clinics in Sub-Saharan African County may use the tests in quantifying proteinuria in this group of subjects. However, a conversion equation for SUPCR and SUPOR are needed for effective use of both methods in quantitative urine protein estimation.

\section{Limitations of the Study}

The sample size is relatively small. A larger sample size preferably involving many centers is desirable. Subjects that took part in the study were not on admission; as a result compliance with strict urine collection may have been compromised by some of the subjects. Ideally the urine should be stored in a fridge at a temperature $2-6^{\circ} \mathrm{C}$ during the collection of the urine, it was not certain that all patient complied strictly with this guideline.

\section{References}

1. National Kidney Foundation (2002) K/DOQI clinical practice guidelines for chronic kidney disease: Evaluation, classification, and stratification. Am J Kidney 39: S1-266.
2. Mallipattu SK, Salem F, Wyatt CM (2014) The changing epidemiology of HIVrelated chronic kidney disease in the era of antiretroviral therapy. Kidney Int 86: 259-265.

3. Redon J (1998) Renal protection by antihypertensive drugs: insights from microalbuminuria studies. J Hypertens 16: 2091-2100.

4. Vassalotti JA, Stevens LA, Levey AS (2007) Testing for chronic kidney disease: a position statement from the National Kidney Foundation. Am J Kidney Dis 50: $169-180$

5. Gaspari F, Perico N, Remuzzi G (2006) Timed urine collections are not needed to measure urine protein excretion in clinical practice. Am J Kidney Dis 47: 1-7.

6. Urinalysis and Collection, Transportation, and Preservation of Urine Specimens: Approved Guideline.

7. Amin SV, Illipilla S, Hebbar S, Rai L, Kumar P, et al. (2014) Quantifying proteinuria in hypertensive disorders of pregnancy. Int J Hypertens 2014 941408

8. Sessoms S, Mehta K, Kovarsky J (1983) Quantitation of proteinuria in systemic lupus erythematosus by use of a random, spot urine collection. Arthritis Rheum 26: $918-920$.

9. Schwab SJ, Christensen RL, Dougherty K, Klahr S (1987) Quantitation of proteinuria by the use of protein-to-creatinine ratios in single urine samples. Arch Intern Med 147: 943-944.

10. Lemann J Jr, Doumas BT (1987) Proteinuria in health and disease assessed by measuring the urinary protein/creatinine ratio. Clin Chem 33: 297-299.

11. Wilson DM, Anderson RL (1993) Protein-osmolality ratio for the quantitative assessment of proteinuria from a random urinalysis sample. Am J Clin Pathol 100: 419-424.

12. Ginsberg JM, Chang BS, Matarese RA, Garella S (1983) Use of single voided urine samples to estimate quantitative proteinuria. N Engl J Med 309: 15431546 .

13. Bland JM, Altman DG (1986) Statistical methods for assessing agreement between two methods of clinical measurement. Lancet 1: 307-310.

14. Antonello VS, Poli-De-Figueiredo CE2, Antonello IC2, Tovo CV3 (2014) Urinary protein-to-creatinine ratio versus $24-h$ proteinuria in the screening for nephropathy in HIV patients. Int J STD AIDS .

15. Chitalia VC, Kothari J, Wells EJ, Livesey JH, Robson RA, et al. (2001) Costbenefit analysis and prediction of 24-hour proteinuria from the spot urine protein-creatinine ratio. Clin Nephrol 55: 436-447.

16. Lane C, Brown M, Dunsmuir W, Kelly J, Mangos G (2006) Can spot urine protein/creatinine ratio replace $24 \mathrm{~h}$ urine protein in usual clinical nephrology? Nephrology (Carlton) 11: 245-249.

17. Leung YY, Szeto CC, Tam LS, Lam CW, Li EK, et al. (2007) Urine protein-tocreatinine ratio in an untimed urine collection is a reliable measure of proteinuria in lupus nephritis. Rheumatology (Oxford) 46: 649-652.

18. Wahbeh AM, Ewais MH, Elsharif ME (2009) Comparison of 24-hour urinary protein and protein-to-creatinine ratio in the assessment of proteinuria. Saudi Kidney Dis Transpl 20: 443-447.

19. Hooman N, Otoukesh H, Safaii H, Mehrazma M, Shokrolah Y (2005) Quantification of proteinuria with urinary protein to osmolality ratios in children with and without renal insufficiency. Ann Saudi Med 25: 215-218.

20. Yang Y, Yian-sheng XIE, Guang-ming LU, Zuo-xiang L, Hua-bin S, et al. (2011) Establishment of equations for predicting 24-hour urine protein excretion and testing of their performance. Academic Journal Second Military Medical University $31: 1113-1117$.

21. Morgenstern BZ, Butani L, Wollan P, Wilson DM, Larson TS (2003) Validity of protein-osmolality versus protein-creatinine ratios in the estimation of quantitative proteinuria from random samples of urine in children. Am J Kidney Dis 41: 760-766.

22. Assadi FK (1996) Random Urine Protein: Osmolality Ratio is a Good Predictor of 24-hr Urine Protein Excretion. Pediatric Research 39: 357-357. 